\title{
THE AESTHETICS OF PARADOX IN LUCIAN'S PROLALIAÍ
}

\author{
Valentina Popescu* \\ University of California, Davis
}

\begin{abstract}
RESUMO: Este artigo explora o emprego, por Luciano, de material paradoxográfico em suas introduções retóricas, prolaliaí, como uma retórica oblíqua de autorreferência. Especialmente, mostra que o material paradoxográfico, gradualmente estabelecendo sofisticados paradigmas para a recepção do novo e da alteridade, é parte de uma estratégia requintada, um sistema referencial complexo, através do qual Luciano define sua poética e reflete o clima cultural multifacetado de sua época, em que tenta estabelecer a si mesmo como, paradoxalmente, uma identidade tanto heterodoxa quanto ortodoxa.
\end{abstract}

PALAVRAS-CHAVE: Luciano; automoldagem; identidade cultural; poética; paradoxo.

à $\lambda \lambda$ à Tí mpòs Tòv $\Delta$ Ióvvбov ó $\Delta$ Ióvuбos oûTos; What has this Dionysus to do with Dionysus?

(Lucian, Bacchus, 5.1)

ucian frequently describes his literary novelty as a marvel parádoxon -, a term typical for paradoxography, the literature of wonders. Yet, in his rhetorical introductions - prolaliai -, the paradoxographical hypotext is pervasive and deserves a more systematic examination, within the broader cultural and literary context. ${ }^{1}$ Lucian exploits the

\footnotetext{
^vpopescu@ucdavis.edu

${ }^{1}$ On Lucian's prolaliaí, see Thimme, op. cit.; Stock, op. cit.; Mras, op. cit.; Anderson, op. cit., 1977; Branham, op. cit., 1985, republished in Branham, op. cit., 1989; Nesselrath, op. cit.; Georgiadou; Larmour, op. cit; Villani, op. cit. References can also be found in more general studies: Bompaire, op. cit., p. 286-288; Reardon, op. cit., p. 165-166; Robinson,
} 
aesthetical and rhetorical functions of marvels (parádoxa), by using them as paradigms for his exoticism, in terms of cultural identity, and the exoticism of his work, in terms of generic identity. ${ }^{2}$

However, the rich and diverse paradoxographical material does more than just presenting the author as exotic; and exotic still sells in the Second Sophistic. ${ }^{3}$ It amounts obviously, in Lucian's case, to more than just a conventional rhetorical repertoire. It goes beyond just equaling the generic novelty of the comic dialogue, or the mixis of genres in it, of prose and verse, of serious and comic, to a parádoxon. Lucian constantly focuses on earning dóxa (fame) through parádoxa from an audience of pepaideuménoi expected to sublimate the experience of ékplexis (astonishment) from bewilderment to aesthetic pleasure. His use of paradoxographical material is part of a more sophisticated strategy. Through the oblique rhetoric of parádoxa, Lucian defines his poetics and reflects the multilayered cultural climate of the era, in which he attempts to establish himself as a, paradoxically, distinct and orthodox identity.

I will limit my study to the eight texts established as prolaliai by Rothstein, given their consistency in scholarly classifications. ${ }^{4}$ The purpose of my study is not to establish taxonomy based on genre purity, which seems a paradoxical attempt for an author who revels with impunity in generic 'impurity'. I only attempt to investigate Lucian's modes of self-presentation filtered through the culture of parádoxa in texts that are self-referential and indisputably introductory. I will discuss Lucian's prolaliai in approximately the same order as Nesselrath (1990), yet not a strictly chronological one, acknowledging that committing to even a loose chronology may prove risky. I divide them into three groups, not completely separate, but in a rather fluid continuity and cross-referential correspondence, based on the development of Lucian's rhetorical skills in incorporating paradoxographical material and on the

op. cit., p. 7-8, p. 13; Anderson, op. cit., 1993, p. 53-55; Pernot, op. cit., p. 547-554; Camerotto, op. cit., p. 266-274 and passim; Whitmarsh, op. cit., 2001, p. 77-78; Brandão, op. cit., p. 7588, p. 91-96, p. 134-138. Cf. Bompaire, op. cit., p. 286, n. 5; Russell, op. cit., p. 77-79.

${ }^{2}$ Anderson, op. cit., 1977, points, in a summary observation, to the presence of paradoxographical material in Lucian's prolaliai, while Branham, op. cit., Camerotto, op. cit., and Brandão, op. cit., briefly discuss it.

${ }^{3}$ Cf. Branham, op. cit., p. 183-184; Anderson, op. cit., 1993, p. 55, p. 171-199; Whitmarsh, op. cit., 2005, p. 35-37. Cf. Gleason, op. cit., passim on Favorinus and his three paradoxes (Phil.VS 489) and p. 39-40 on the possible use of parádoxa in Polemo's introductions.

${ }^{4}$ Rothstein, op. cit., p. 116-123. 
self-referential statements concerning cultural identity: a first group, in which the author is concerned with establishing an audience and blending in with the Greek culture (Harmonides, Herodotus, The Scythian, The Dipsádes), a second, with establishing a degree of difference in the reception of his work not as mere novelty, but also as exquisite artistry (Amber or Swans, Zeuxis or Antiochus), and a third, with reestablishing himself after an alleged absence from the rhetorical arena (Heracles, Dionysus).

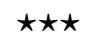

Harmonides has earned only very short treatments, at most a few lines. Not only is its artistic value obviously inferior in comparison with the rest of Lucian's prolaliai, but it also proves hard to fit into any compositional pattern. ${ }^{5}$ Harmonides, a hopeful young pipe player, asks Timotheus, who has already taught him perfectly the art of pipe playing, to teach him also how to acquire general fame, for him the final purpose of art. ${ }^{6}$ Harmonides wants to be distinguished (' $\varepsilon$ míonuov) among men like his teacher, whom people admire just as day birds regard a night

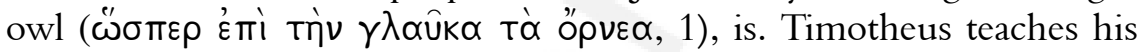
disciple that the shortest path to glory is not to seek the admiration of the

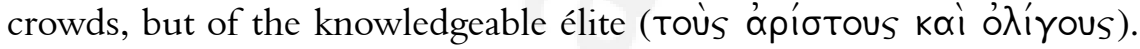
They, as leaders of opinion, are able to influence the masses, people of

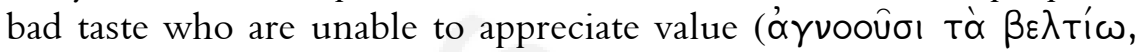

\footnotetext{
${ }^{5}$ Cf. Anderson, op. cit., 1977, p. 314-315; Nesselrath, op. cit., p. 121; Anderson pairs it with Somn. and distinguishes three common thematic elements: "the would-be artist prefers fame to a life of obscurity", "his first youthful essay is his last", and "a trial scene".

${ }^{6}$ There is no other extant source for this anecdote. Timotheus is a famous fourth century Boeotian pipe player (Diphil. fr. 78 Kassel-Austin; Dio Chrys. Or. 1. 1-3; Athen. Deipn. 12.54.34; Phot. 243.372 a 37-40. His musical performance produced a strong impression on Alexander the Great (Dio Chrys. Or. 1. 1-3; cf. Suda T 620, 7 13, where Timotheus of Thebes is confused with Timotheus of Miletus (Suda T 620, 1-7); cf. Suda $\propto$ 1122, o 573; Anna Comn. 4.1.16-21; Eust. Comm. ad Il. 3.137.1213. The story is celebrated by Dryden and adapted by Hamilton to a libretto for Handel's Alexander's Feast). This Timotheus needs to be distinguished from the 5-4 c. musician and citharode Timotheus of Miletus (Luc. Harm. 1. 24; cf. Arist. Metaph. 993 b15; Diod. 14.46.6.5; Plut. De Alex. fort. 334 b; Steph. Byz. 452.16-453.4; Phot. Bibl. 239. 320 b 10-11; see West, op. cit., p. 361-364; Campbell's Greek Lyric, vol. 5, 1993, p. 70-121; Hordern, op. cit.). On Timotheus of Thebes/ Miletus see Bélis, op. cit., 1998 and 2002.
} 


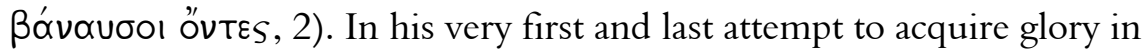
a competition, Harmonides blows too ambitiously and breathes out his life into his pipe, thus dying uncrowned. ${ }^{7}$ In a disproportionately long sýncrisis Lucian claims to apply Timotheus' principles to himself and his epideixis on a short road to fame. He launches into excessive and rather clumsy flattery of an unnamed patron, whose opinion exceeds

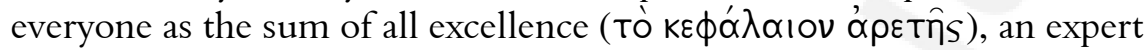

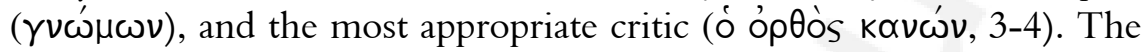
utmost expression of doxa is articulated here through a parádoxon. The élite's admiration of the artist is illustrated by the wonder felt by birds

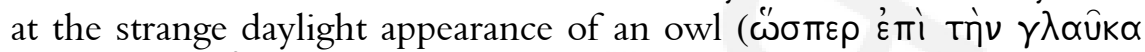

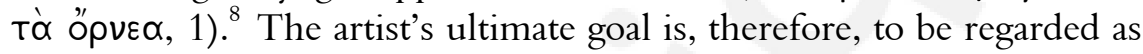
a marvel, as a surprising, astonishing, exotic entity. Herodotus or Aëtion is a diptych prolaliá. In the two illustrative stories, the historian Herodotus and the painter Aëtion gain universal recognition by displaying their talents at Olympia. Herodotus travels to mainland Greece to gain quick and easy fame. He allegedly decides to perform at Olympia, during the games, before an élite audience representing the entire Greek nation. ${ }^{9}$

\footnotetext{
${ }^{7}$ Paradoxically, although Harmonides dies without glory, he nevertheless gains posthumous fame through this story, whether as part of a shared tradition, or through Lucian's invention. Lucian uses here elements of the common stock sophistic material later recommended by Menander Rhetor for introductory speeches, e.g. the mention of famous citharodes and pipe players (Men. Rhet. 392.19-20). Lucian speaks here of the two Timotheuses, of Marsyas, the legendary Phrygian aúlosplayer, and of Olympus, Marsyas' legendary pupil (cf. Pl. Symp. 215 c). Timotheus of Thebes, Marsyas, and Olympus appear all in one of Dio Chrysostom's prolaliaí (Dio Chrys. Or. 1. 1-3). One of Apuleius' introductions tells the story of Marsyas, while another makes mention of another famous aúlos-player, Antigenidas (Apul. Fl. 3 and 4).

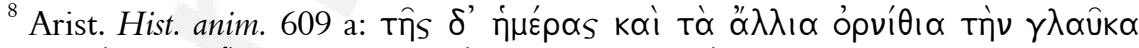

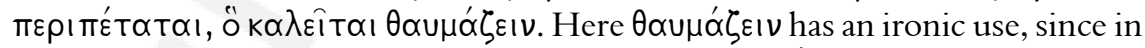
fact the little birds pluck the feathers of a confused owl (

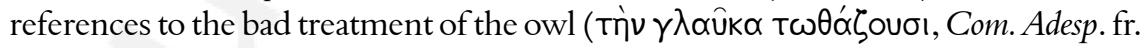
724 Kock; cf. Ael. Dion. T 15; Phot. Lex. т 586), and to the owl's strange walk, like a dance, during the day (Suda $\alpha 137$ on Call. Hec. fr. 326; cf. Hesich. Lex. Y 610). On the seducing power of the owl see Ael. $N A$ 1.29. Lucian seems to employ here a paradoxographical imagery, that of the exotic sight of an owl during the day.

${ }^{9}$ See Johnson, op. cit., p. 240-242 and Nesselrath, op. cit., p. 117-118 on the improbability of these facts; cf. Euseb. Chron. Arm. 83; Didyllus FGrH 73 F3; Plut. Herod. mal. 862 A 6-8.
} 
Herodotus prefaces his display by affirming his status as a performer competing for recognition, not a passive spectator (ou' $\theta \varepsilon \alpha \tau \eta \dot{\nu} \nu, \alpha^{\prime} \lambda \lambda$ '

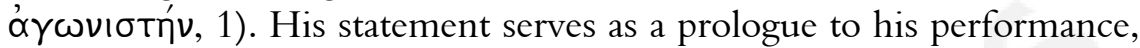
through which he obliquely aims at the audience's attention and their favorable judgment, a metaliterary paradigm for Lucian's own prolaliá and its function. ${ }^{10}$

Herodotus enchants his audience with the recitation of his Histories

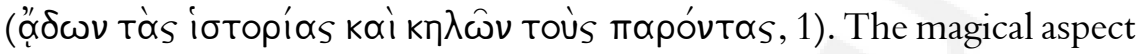
of the performance makes it extraordinary, thus equivalent to a marvel. As magic charming is associated with both pleasure and deceit, the charm of parádoxa is transferred for Herodotus - the "father of history", but also "of lies" - to his performance of a text whose fabric is dappled, in the spirit of poikilia, with marvels ( $\theta \omega \mu \alpha \tau \alpha) .{ }^{11}$ In Lucian's case, on the other hand, the expression of dóxa lies in the beholding of a charming performance perceived as an aesthetic marvel. Paradoxically, in both Harmonides and Herodotus, Lucian represents the élite's ideal reception as a reaction characteristic of the masses: shocked and curious little birds flocking around an owl in the middle of the day, or crowds bewitched by the marvellous stories of a mendacious charmer. The paradoxographical imagery evokes strong irrational emotions, attributed elsewhere by Lucian to a rather untrained audience. ${ }^{12}$ Here, however, it vividly translates the intensity of aesthetic emotions. The epideixis, perceived as an aesthetic parádoxon, produces not just a cerebral reaction, but also a strong emotional response, as admiration for téchne is elevated to wonder and awe.

These two prolaliai share striking similarities in terms of theme and motifs. They are both articulated on the idea of fame ( $\tau ા \mu \eta \dot{\text {, }}$ $\delta \delta^{\prime} \xi \alpha$ ), particularly on the shortcut ( $\dot{\eta} \varepsilon$ mítouos) to universal renown. This shortcut is facilitated by the élite, whose paideía makes them not only appropriate judges, but also leaders of opinion, able to shape the artistic and cultural judgments of the non-élite. ${ }^{13}$ While in Harmonides Lucian avoids the issue of ethnicity and cultural identity altogether, in Herodotus he seems to be one step further on his cultural homecoming journey. Following on Herodotus' steps, Lucian crosses the sea from

\footnotetext{
${ }^{10}$ Cf. Dio Chrys. Or. 8.11 on Diogenes' similar attitude.

${ }^{11}$ Cic. Leg. 1.5, Div. 116; cf. Luc. VH 2.5, 2.31. Evans, op. cit.; Hartog, op. cit.

${ }^{12}$ Luc. Zeux. and Prom. es.

${ }^{13}$ Luc. Harm.2.13; Herod.3.1. Cf. Luc. Rhet. praec. 3.11, where Lucian satirizes the shortcut to rhetorical fame facilitated not by paideía, but by simulation of paideía.
} 
the east to his own Olympia, in fact Macedonia. ${ }^{14}$ Herodotus comes from a marginal area, therefore he is perceived as foreign to mainland Greece and mainstream Hellenism. However, not only is he able to enchant the Greek élite, but he also sets the foundations of a new cultural pattern, thus paving the way for other artists who will display their work at Olympia. The list of Herodotus' followers on this shortcut to fame opens, suggestively, with the name of Hippias of Elis. In virtue of the Eleans' control of the Olympic Games, Hippias appears as a native of the sacred ground that stands for Greekness as the cement of a nation. Thus, he epitomizes the very core of the Greek élite. By making Hippias a follower of Herodotus, Lucian affirms the ability of an Asian to bring innovation to all Greece and become a model for all Greeks. Not only does an outsider conquer Greece, but he also teaches Greeks a cultural lesson, thus incorporating fringe elements previously perceived as foreign and marginal.

In his praise of the Macedonian host city Lucian, in zealous flattery, disparages Olympia and its spectators in favor of the present location and audience. Thus, sacred old symbols of Greekness are reduced to primitivism and lack of paideía. It is time for new symbols and new canons, the inclusion of the marginal areas of the Greek world. In changing the center from Olympia to Macedonia, Lucian points to a pattern for other fringe territories that can be incorporated and usurp the old center's birthright. On the other hand, Herodotus' path is a paradigm for Lucian's own path from the margin to the center, for his

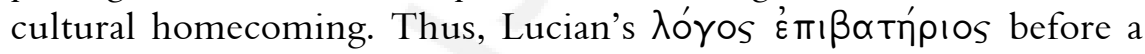
Macedonian audience becomes from a visitor's speech a cultural homecoming speech, in an attempt to change his cultural status, from a visitor to a native of Greek letters. ${ }^{15}$

Aëtion exhibits at Olympia his representation of the wedding of Alexander and Roxana, a painting that Lucian claims to have seen in Italy. ${ }^{16}$

\footnotetext{
${ }^{14}$ The performance has been placed in Thessalonica (Gallavotti, op. cit., p. 6) or Beroea (Jones, op. cit., p. 11 n. 25).

${ }^{15}$ In Menander's taxonomy, this introductory speech, if taken individually, would

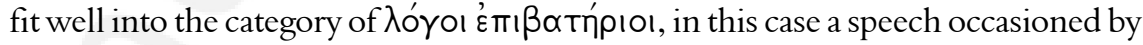
the rhetor's visit to a city other than his native one. As such, it should, as it does, contain praise of the host city and its leadership (Men. Rhet. 377.31-378.3); cf. Nesselrath, op. cit., p. 117.

${ }^{16}$ Cf. Nesselrath, op. cit., p. 119-120. For Aëtion cf. Luc. Merc. cond. 42.2, Imag. 7.16, 7.26-8.1; Pl. NH35.78, 34.50.
} 
Proxenides, one of the judges, is so pleased by such a display of talent, that he offers his daughter in marriage to the painter. Displaying his own skills of "painting with words" in an ékphrasis, Lucian does not address the relevance of this story. ${ }^{17}$ Aëtion's skills make possible the transfer of art that imitates reality (i.e. the wedding of Alexander and Roxana) to a new reality that involves the artist himself (i.e. his own wedding). This anecdote becomes paradigmatic of Lucian's hope to emulate the painter and to transfer, through his rhetorical skills, fame from logos to actuality. The Olympian judge who marries his daughter to the stranger (ou'k $\varepsilon \Pi ı \chi \omega \rho i \omega)$ Aëtion is $\Pi \rho \circ \xi \varepsilon v i \delta \eta s$, the son of a $\pi \rho \xi_{\varepsilon v 0 S}$ (host/friend/ protector offoreigners; patron). Therefore, his inclusion of Aëtion into the family expresses Lucian's expectation to be embraced, as a xénos (friend), by his influential audience/ hosts/ patrons into the family of Greekness. ${ }^{18}$

In The Scythian, also delivered in Macedonia, Lucian develops further the concept of proxenía. He compares the cultural relationship between himself and his próxenoi, Macedonian father and son, to the relationship between the Scythian Anacharsis and his próxenoi, Toxaris and Solon, one a former compatriot now completely Hellenized, the other a genuine Athenian epitomizing the best of Greece. ${ }^{19}$ Lucian works here with two different forms of parádoxa: exotic, illustrated by the contact between two different cultures, Greek and barbarian; and aesthetic, represented by Greek paideía, especially in the form of rhetorical display.

\footnotetext{
${ }^{17}$ Luc. Dom. 21.14, Calumn. 2.1-2.

${ }^{18}$ It is also significant that Lucian invokes Zeus $\Phi_{1}^{\prime} \lambda_{1} \circ$ s, the god of friendship (Luc. Herod. 7).

${ }^{19}$ Both of the names 'Anacharsis' and 'Toxaris' appear in two other Lucianic works, the dialogues Anacharsis or On Athletics and Toxaris or Friendship. Visa-Ondarçuhu, op. cit., argues for the same identity of the characters bearing these names; cf. Anderson, op. cit., 1976, p. 267-269. While the character of Toxaris seems to be entirely Lucian's invention in both cases (cf. Kindstrand, op. cit., p. 13-14 n. 27; Gorrini, op. cit.), Anacharsis is well established as a Scythian wise man in the earlier Greek literary tradition, with a notable resurgence in the Imperial literature; cf. Hdt. 4.46, 76-77; Hermipp. (apud Diog. Laert. 1.101-105); cf. Ps.-Anacharsis Ep.; Plut. Sol. 5.1-6, Mor. 146b-164d; Athen. Deipn. 4.49, 10.32, 50, 64, 14.2; Max. Tyr. Or.25.1; Dio Chrys. Or. 32.44; Nic. Dam. FGrH 90 F104; Gal. Adhort. ad artes 17; Ael. VH. 2.41, 5.7; Fronto Ep. Graec. 1.5; etc. For a complete list of sources, see Kindstrand, op. cit., and Ungefehr-Kortus, op.cit.
} 
Anacharsis, enamored with Greece, comes to Athens, reenacting the journey of Toxaris. While the Athenians make fun of his barbarian appearance, he is perplexed and frightened at the encounter with a new

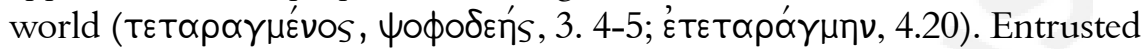
by Toxaris to Solon, his patron, Anacharsis is initiated in Greek paideía and thus, conquering novelty through understanding, his bewilderment

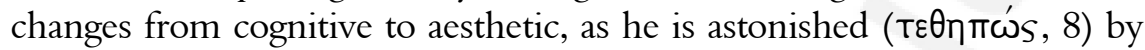
Solon's sophía. While the theme here is still the shortcut to fame, the focus subtly shifts from the idea of dóxa to that of proxenía, from achieving literary glory to achieving a more inclusive cultural embracing, not just as an artist, but - more importantly - as culturally Greek.

Travel and displacement lead to the experience of the otherness, to the shock of novelty, which those writers of parádoxa who claim autopsy confess to have undergone themselves and to which they attempt to expose their readership. Anacharsis' journey is not just physical, but also cultural. He is engaged in theoria, in seeing the world, here reduced to Greece. ${ }^{20}$ His interests in foreign customs echo those of a paradoxographer. ${ }^{21}$ Although Lucian emphasizes the emotional effect of parádoxa on Anacharsis, he also refers to them in terms of

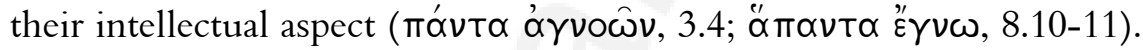
$\mathrm{He}$, thus, makes the Scythian's effort distinctive from that of the paradoxographer proper, who records marvels aiming at creating shock, not understanding. His readership enjoys the pleasure of the emotional effect and escapes the rationalizing effort. For Anacharsis, however, parádoxa, to which he is keen to be exposed, represent a novel world that fascinates him, yet which he attempts to understand.

While for Anacharsis, Toxaris, and Solon, Lucian stresses the idea of

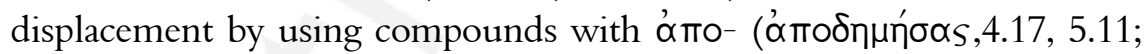

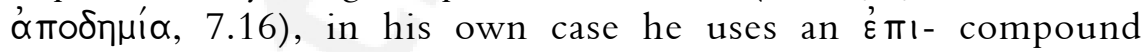

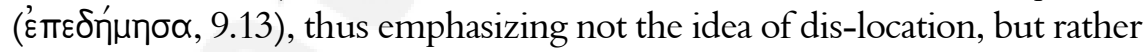
that, which comes as its possible consequence, of re-location, of putting down roots in a new place. One could even stretch the use of the verb $\varepsilon \pi \sqcap \delta \eta \mu \varepsilon \omega$ here to deliberately imply the idea of (cultural) homecoming.

${ }^{20}$ Cf. Luc. VH 1.2.4; cf. Hdt. 1.30 on Solon's journey and theoría (тñs $\theta \varepsilon \omega p i ́ n s$

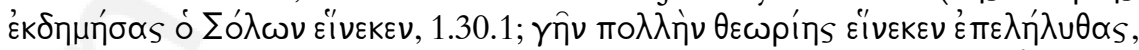

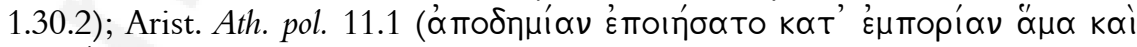

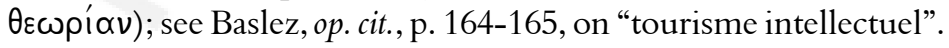

${ }^{21}$ Hdt. 4.76-77; Nic. Dam. FGrH 90 F104.9.11; Dio Chrys. Or. 32.44; Diog. Laert. 1.101; Ps.-Anacharsis Ep. 10.1-3. 
Lucian, who identifies with Anacharsis, confesses to have had a similar emotional experience when he first came to the Macedonian city where he is performing:

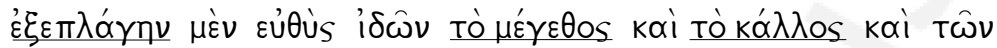

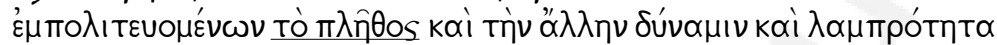

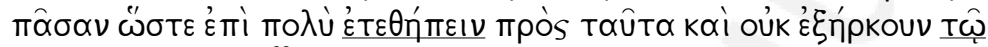

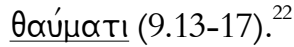

The object of Lucian's bewilderment is an aesthetic parádoxon

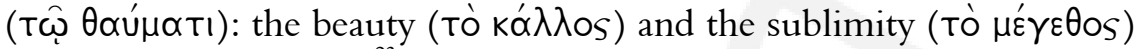
of the Macedonian city. ${ }^{23}$ Indeed, the marvelous beauty of Greek paideía

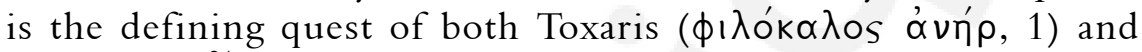
Anacharsis. ${ }^{24}$ We find its greatest expression in Lucian's young Macedonian próxenos, with whom the city is passionately in love and whose physical beauty is matched by speech:

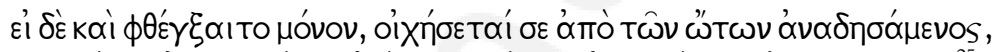

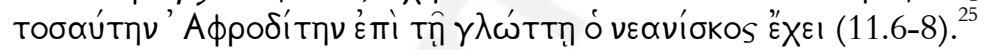

Lucian's construction of parádoxa develops fully here from exotic to aesthetic, to astonishing beauty epitomized by Greek paideía,

22 "I was immediately so astonished when I saw the greatness and beauty of your city, its huge population, all its might and splendor, that I was in amazement for quite a long time and my marveling could not match the marvel itself"./ Cf. Lucian'

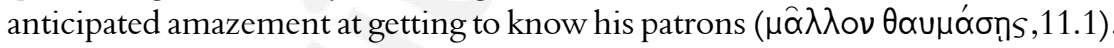

${ }^{23}$ For the ancient rhetoricians $\mu \varepsilon \gamma_{\varepsilon} \theta 0$ s is sublimity of style: Dion. Hal. Comp. 17; Dem. Eloc. 5; Hermog. Id. 1.5; Ps.-Long. 4.1. In his taxonomy of marvels, Giannini, op. cit., p. 249-251, recognizes under the category of aesthetic $\theta \alpha u ́$ ua $\alpha \alpha$ the extraordinariness of beauty or greatness $\left(\theta \alpha \hat{v} \mu \alpha=\pi \varepsilon \rho ı \alpha \alpha \lambda \varepsilon^{\prime} s\right.$ vel $\left.\pi \alpha \mu \mu \varepsilon^{\prime} \gamma \varepsilon \theta \varepsilon s\right)$, found either in a work

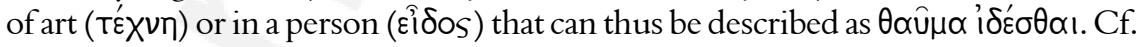
Luc. Herod., where a Macedonian city compared with a famous place of Greece, Olympia, is in the end deemed even superior to it; here the greatness of the Macedonian city, indirectly compared with Athens, is not emphasized by contrast, but only by positive association, by building up upon the greatness of Athens.

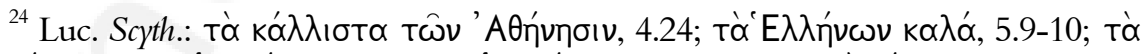

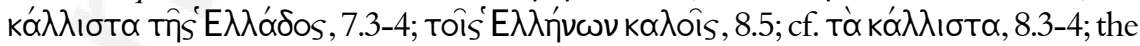

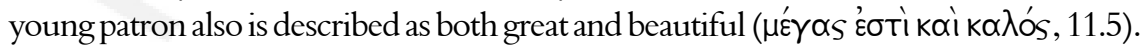

25 "If he only opens his mouth, he will leave you enchained by your ears, so much of Aphrodite the young man has in his tongue"./ Cf. Luc. Herc. 3. 
particularly by rhetoric, Lucian's own craft. It inspires ékplexis, the typical response to marvels, as well as love, here a higher form of ékplexis. ${ }^{26}$

Lucian's relationship with his próxenoi, one of cultural patronage, takes expression in a mixture of proxenía and philia (11), both inner- and intercultural friendship. Thus, he claims to be at the same time a foreigner and a citizen of Greece as a cultural paradigm. However, unlike Anacharsis, whose experience of Greekness starts from ignorance and evolves to complete familiarity, for Lucian Greekness - here represented by the city and by his patrons - is a parádoxon only in terms of beauty, not of novelty. Therefore, he already feels Greek; he only needs to be acknowledged as such.

While in The Scythian Lucian uses the imagery of marvels for paideía and rhetorical performance, in The Dipsádes he describes the relationship between the performer and his audience as a parádoxon. Lucian invites the audience to explore the North African desert with its oddities and to walk a fine line between fact and fiction. ${ }^{27}$ This blending epitomizes the essence of the rhetorical art, the skill of incorporating subjective reality into the objective. After a long list of parádoxa, he comes to the greatest: $\dot{\eta} \delta ı \psi \alpha ́ s$ - the thirst-snake, into which the features of the parched desert landscape are sublimated. Besides emphasizing it with a double mythological parádoxon, the water related punishment of Tantalus and the Danaids, ${ }^{28}$ Lucian articulates the story of the dipsás also as a logical paradox that leads to aporía:

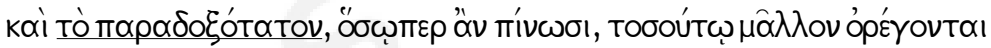

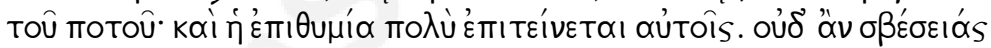

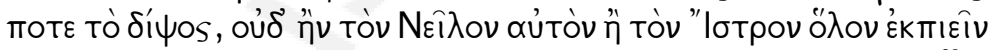

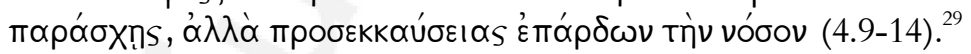

\footnotetext{
${ }^{25} \mathrm{Cf}$. Segal, op. cit., on love as ékplexis and forgetfulness of nómos in Gorgias' Helen; cf. Belfiore, op. cit., p. 137-138, p. 144.

${ }^{27}$ Cf. Hdt. 2.32 and 4.181-199 for the description of North Africa; on the dipsas, Nic. Ther. 124-127 and 334-342; Ps.-Diosc. Ther. 13 (ed. Sprengel, in Künn, Medici Graeci, vol. 26); Philum. Ven. 20.1-3; Aret. CD 2.2.5; Ael. NA 6.51; Alex. Aphr. Pr. 1.152; Afric. Cest. 3.30; cf. Dio Chrys. Or. 5 on the myth of a monstrous Libyan creature, half woman-half snake (cf. Or. 4.73); for a comparison between Luc. Dips. and Dio Chrys. Or. 5 see Nesselrath, op. cit., p. 122 n. 19; cfArist. Hist. an. 606b 9-14 on monstrous snakes of Libya. ${ }^{28}$ Cf. Giannini, op. cit., p. 250 and n. 12 on mythological marvels ("meraviglioso fiabesco: nella $\left.\mu \cup \theta 0 \lambda \circ \gamma^{\prime} \propto, \theta \hat{\alpha} \cup \mu \alpha \neq \alpha_{\alpha} \lambda \hat{n} \theta \varepsilon ı \alpha\right)$.

29 "And the strangest thing of all is that the more the victims drink, the more they yearn for water and their craving increases terribly. You could never quench their thirst, not even if you give them the Nile itself or the entire Ister to drink dry, but instead you would only grow the burning by watering the disease".
} 
The parádoxon is expressed in hyperbolic images and uses geographical references familiar to the literature of marvels. Both the Nile and the Ister border exotic, unexplored lands. ${ }^{30}$ The logical paradox is anticipated by the startling statement that water causes fire:

ă

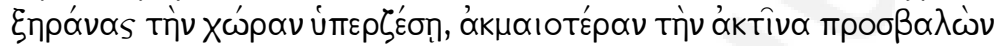

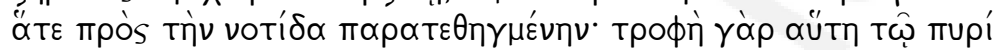
$(2.17-21) .^{31}$

On these parádoxa Lucian projects his own: he feels for his

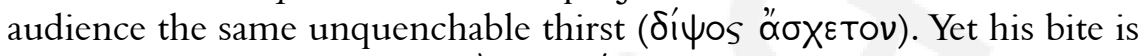
not physical, but spiritual (тทंv $\psi \cup \times \dot{\eta} v$ ), not poisonous and sickening,

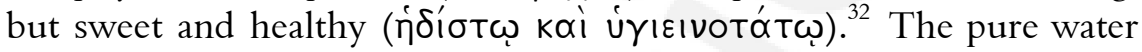
fueling his thirst is his élite audience, more precisely, his coming before

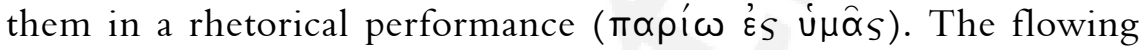
streams of water represent the image of an audience flocking to hear him perform and eagerly listening to his speech (9). Lucian's own

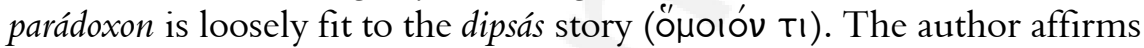
clearly that he is the victim and the audience is the ever desired water that causes both relief and longing, sick desire and health. Yet the dipsás is absent from the equation of the applicatio. The sweet poisonous snake is arguably the unresolved metaphor for literary fame. Just as the dipsás bites its victim inflicting thirst for water, the desire for fame drives Lucian to perform before the élite again and again. His thirst for rhetorical performance implies positive reception that builds fame.

The story of The Dipsádes lies on the fringe between paradoxographical and scientific/ didactic discourse. Its factuality is challenged by the comparison with other well-known texts that claim not only more reliable sources, but also the status of true discourse. Nesselrath makes a commendable effort to explain the incongruence of Lucian's account on the North African desert with that of Herodotus and Pliny the Elder.

\footnotetext{
${ }^{30}$ For the Ister, cf. Mir. ausc. 105, 168. For the Nile, cf. Antig. 162; Mir. ausc. 166; cf. Hdt. 2.33-34; Arist. Hist. an. 7.4.584b; Plin. HN 1.33,39,272; Gellius NA 10.2. Cf. Beagon 2005, 150-151, 164-166; 185. See Fraser, op. cit., 1, p. 176-177 on the Ptolemaic expeditions in exploration of the Nile.

31 "There is no escape from the desert if the sun boils over, drawing out the moisture and quickly parching the land, casting stronger rays, as if sharpened by humidity; for moisture fuels the fire".

${ }^{32}$ Luc. Nigr 38 and Philops. 40.
} 
He attributes it to an inconsistent mixture of the sources, some of which give conflicting information themselves. ${ }^{33}$ Yet this approach tends to read too much into Lucian's account and to attribute to him serious intentions regarding the factuality of his report.

On the contrary, Lucian repeatedly makes the effort to separate himself from this information and to undermine its reality. The paradoxographer proper does not rely on autopsy, as paradoxography offers only "a tour effectuated within the walls of a great library", thus just an inquiry into written sources. ${ }^{34} \mathrm{He}$, nevertheless, emphasizes the documentation of his accounts by producing plausible sources and/ or by critically evaluating them. Therefore, he acknowledges his focus mostly on reporting information based on inquiry into sources (iбторía), rather than on attempting a reasonable explanation ( $\left.\varepsilon^{\prime} \xi \eta^{\prime} \gamma \eta \sigma / s\right) .{ }^{35}$ Lucian too confesses lack of autopsy and, even more, in an ironical turn, the absolute lack of desire for autopsy:

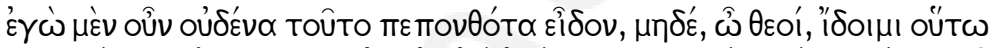

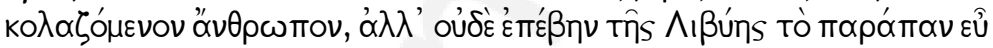

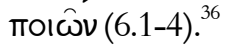

Yet, on the other hand, Lucian is deliberately far more evasive and less credible when it comes to his sources: he heard the report from a friend, who had seen a funerary monument and its inscription, both representing, in artistic form, the story of a dipsás victim (6). Thus the reality itself is twice filtered before reaching Lucian, who himself gives now his own artistic version of it. The process of his inquiry is, therefore, severely - yet deliberately - compromised.

While his documentation is, therefore, poorer than that of the paradoxographer proper, Lucian still squeezes in, however under the guise of historía, some sort of scientific explanation, exégesis. This, because attributed to doctors, may present the appearance of authenticity (5). Although not the result of the author's own rationalizing attempt, it may falsely give the impression of such design on his part. Thus, Lucian skillfully plays on the edge between paradoxography and paradoxographical discourse incorporated into other genres, where the historiographer,

\footnotetext{
${ }^{33}$ Hdt. 2.32 and 4.181-199; Plin. HN 5.26. Nesselrath, op. cit., p. 123-124.

${ }^{34}$ Cf. Schepens, op. cit., p. 388.

${ }^{35}$ Cf. Schepens, op. cit., p. 382-390, especially 390 with the discussion of Antig. 60.

36 "I have seen nobody suffering this torture and, oh gods!, may I never see a man punished in this way; but then, fortunately for me, I have never set foot in Libya".
} 
for instance, who makes use of parádoxa, besides often backing up inquiry with autopsy, addresses - at least sometimes and even if poorly - the question of causality. Lucian even flirts, again within the realm of historia, with the idea of autopsy, yet not his own, but of his source. Moreover, even the eyewitness saw not the reality of a dipsás victim, but a stone relief and an epigram, both art objects testifying to it, as Lucian identifies ironically here autopsy with reading ( $\varepsilon^{\prime \prime} \lambda \varepsilon \gamma \varepsilon \nu$ aútós). This, combined

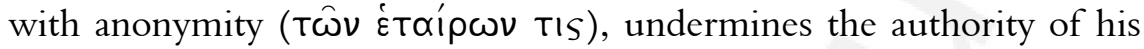
alleged eyewitness source (6).

Furthermore, in this playful rope-walking between fiction and the appearance of truthfulness, Lucian claims he only remembers part of the sepulchral epigram, specifically the four lines that describe in mythological similes the terrible suffering of the dipsás victim. Thus, not only is the evidence limited to reproducing a friend's ekphrastic report of a funerary monument and his recollection of its epigram, both art objects already one step removed from the parádoxon itself; it also becomes questionable when Lucian acknowledges his poor memory of the source. Yet the final blow to any deceiving illusion that he might claim factuality for his report is the strong statement through which Lucian overtly separates himself and his design from scientific/ didactic discourse (9).

Thus, although obliquely criticizing the literature of parádoxa as avowed true discourse, Lucian uses parádoxa himself here at two separate levels. He exploits them, just like a paradoxographer, to please the audience with strange stories. What better captatio than in an introduction? However, without making any strong statement on the truth-value of parádoxa, he gives the appearance of factuality only to undercut it through subtle inconsistencies with the paradoxographer's methods. On the other hand, he exploits a different, sublimated value of parádoxa, of stylistic order, when he applies them as sophisticated similes and metaphors for self-reference.

In Amber or Swans, Lucian plays again on a slim edge between factuality and fiction and projects a deceiving self-image. While in The Dipsádes he leaves classical Greece, the ambiance of the presumably earlier prolaiaí, for an exotic Libya with anachronistic Hellenistic savor, here Lucian engages the audience in his alleged travel to northern Italy, mixing up mythological time and space with his present reality. Although repeatedly claiming naïve credulity with respect to mythological stories, Lucian ironically hints at their ludicrousness. ${ }^{37}$ The illustrative story

${ }^{37}$ Cf. Nesselrath, op. cit., p. 126-127; Camerotto, op. cit., p. 183 n. 39. 
contains mythological parádoxa focused on metamorphoses from human shape into a river (Phaëthon), into poplars dropping amber tears (the Heliades), and into sweet singing swans (Cycni), all concentrated around the mythical river Eridanus. ${ }^{38}$ Thus, mythological marvels are built on natural and aesthetic parádoxa (miraculous physical changes and the sweet song of the swans).

The key-terms in Amber or Swans are credulity, expectation, and finally disappointment. ${ }^{39}$ Lucian tells here a story of enchantment and disenchantment. Under the spell of poetic mýthoi, of 'wretched tales of poets', he goes in search for amber and swans. Instead, the locals laugh at him, showing that all these stories about their land were lies and nonsense. His disenchantment is presented in terms of a strong contrast between expectation and reality. His childish credulity and the propensity to transfer mythical marvels into reality and historical time are in discrepancy with the poverty and toil of the people living in a land allegedly rich in amber. ${ }^{40}$ With their ironical laughter, they shake off the spell of parádoxa for the naïve traveler. For the readers of parádoxa, marvels are their only measure of a remote reality which they cannot check, because they do not travel to exotic lands unless through books. Lucian attempts the impossible journey to the reality of mythoi, to experience in real life the wonder he felt as a credulous reader. The reality check however is disappointing, since the literary space filled with parádoxa is identified with a desolate real space.

His own experience of brutal change from enchantment to disenchantment is transferred by Lucian from his own story to his audience:

\footnotetext{
${ }^{38}$ Eur. Hipp. 732-751; Diod. 5.23; Ov. Met. 2.324-380, 7.371-379, 12.64-171; Pl. Phaed. 85; Plin. NH 10.32; Cic. Tusc. 1.30; Hyg. Fab. 152, 154; Luc. Dial.D. 24.3.

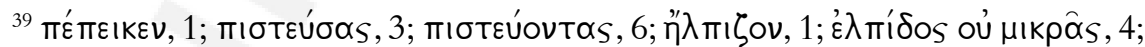

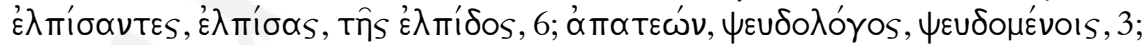

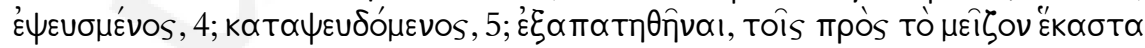

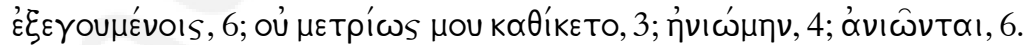

40 "If there were such a thing [i.e. amber], do you think that, for two obols, we would row or pull our boats upstream, if we were able to get rich by picking up the

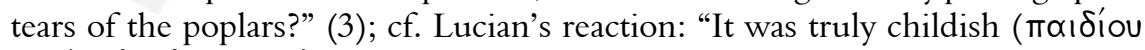
TIvós $\left.\omega_{S} \alpha \lambda \eta \theta \omega_{S} \stackrel{\varepsilon}{\varepsilon} \rho \gamma o v\right)$ to have believed the poets who falsely speak about

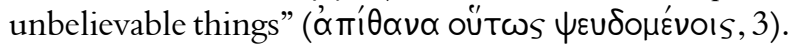




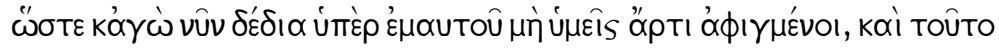

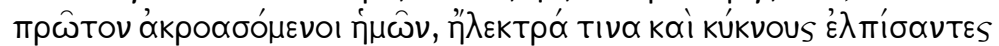

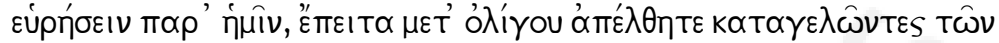

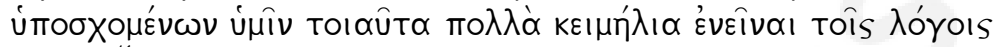
$(6.3-8){ }^{41}$

An important element is present in both cases: there is always a third, a mediator between the perceiver and that which is perceived, the authors who lie in mýthoi, on the one hand, and the people who wrongly exaggerate Lucian's qualities, on the other. Thus, Lucian and his rhetoric become the mythoi. The text ends with yet another illustration of false perception due to a third. Objects seen under water are distortedly enlarged and one needs to remove the distorting lens to see their real dimension. Lucian stresses, therefore, the importance of autopsía and of the use of one's own critical judgment in forming dóxa. ${ }^{42}$

The text opens itself to two levels of reading, one based on what it says, another on what it conceals, or rather subtly pours into the ears of the audience. At one level it deals with the expectations of a new audience and serves what Brandão calls "uma retórica da diferença". ${ }^{43}$ Lucian clearly separates himself from other authors, the poets who tell lies and the sophists of his time whom he ironically praises in terms of gold. ${ }^{44} \mathrm{He}$ also separates himself from his own fame created by others and thus, by destroying an existing false expectation, he creates a new one, an

41 "Therefore, I too am now afraid on my account that you, who have just arrived and are about to hear me now for the first time, expecting to find in me some amber and swans, may later leave laughing at those who promised that many such treasures were in my speeches"./ Cf. the preceding gnome: "With respect to many such things people can be deceived, while they believe those who relate everything

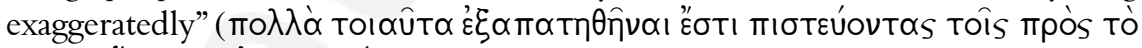

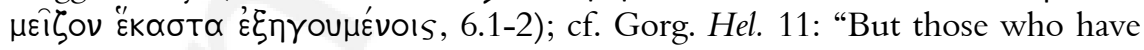
persuaded and still persuade so many people, about so many things, are forgers of

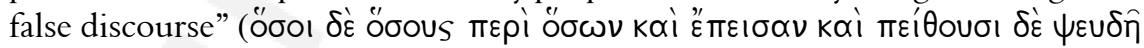

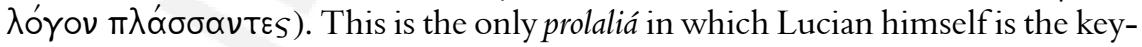
character in the anecdote that serves as applicatio for the context of performance; Nesselrath, op. cit., p. 126.

${ }^{42}$ Lucian himself incurs the risk of being a third when he narrates the mythological stories to the locals who, however, have the advantage of autopsía and do not fall victim to his enchantment, but on the contrary disenchant him.

${ }^{43}$ Cf. Brandão, op. cit., p. 76.

${ }^{44}$ Cf. Luc. Prom. es 1 where the same praises are showered on the forensic rhetors. 
expectation of the difference. ${ }^{45}$ Lucian addresses here mainly a new audience. They are, however, already under the spell of a false dóxa. His attempt to educate a new public, therefore, turns into an act of reeducation, of disenchantment. Lucian makes Eridanus, as the setting of deceiving parádoxa tales, the paradigm for authors who claim the reality of the marvels they write, a guild from which he clearly separates himself. ${ }^{46}$ In his use of parádoxa stories, he does not exploit their alleged factuality, but their obvious lack of reality. He claims that his search for mythological marvels was not the purpose itself of his voyage, but only a marginal diversion from it, an accessory of his main rhetorical journey. He, thus, reduces his marvel stories to their traditional role of mere entertaining digression in more noble literary genres. Yet, this is an inverted manner of paradoxo-graphia, in which the astonishment effect is undermined by revealing the falseness of parádoxa. Ékplexis, however, as aesthetic emotion, is transferred from these pseudo-parádoxa to the author himself, in a paradoxical self-introduction. The author becomes the parádoxon here, defying the dóxa that his audience has of him.

At another level, Lucian uses the paradoxographical hypotext to hint at his own deceit in self-presentation. In an alleged demystification

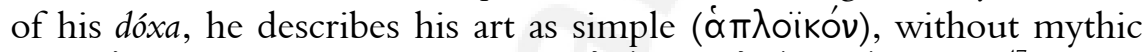

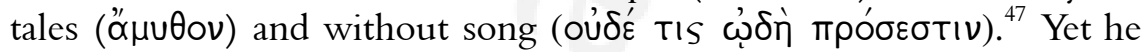
emphasizes that his audience must have already noticed these qualities during the current performance (ópôte $\eta \hat{\delta} \eta, 6$ ). However, up to this point, his text has been all but simple - in fact, full of metaphors that bridge intricate correspondences; all but $\alpha^{\prime} \mu u \theta 0 \nu$ - since mythical marvels are its foundation; and all but non-musical - one has only to listen to its first sentence and notice its exquisite rhythmic construction. ${ }^{48}$ Thus, by claiming to disenchant his audience, he enchants them even more.

${ }^{45}$ Cf. Brandão, op. cit., p. 76.

${ }^{46}$ Cf. Luc. VH 1.1-4.

${ }^{47}$ Cf. Villani, op. cit., p. 228.

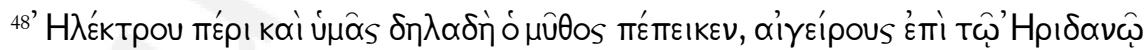

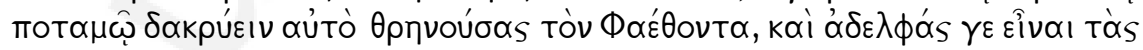

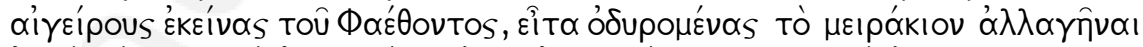

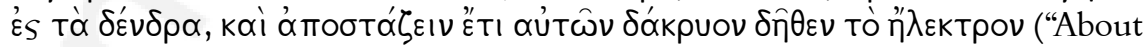
amber, you too, certainly, believe the story that poplars on the banks of the river Eridanus shed it in their tears, lamenting Phaëthon, and that those poplars are the very sisters of Phaëthon, and that, while mourning their young brother, they were turned into trees, and that the amber, clearly their tears, still drips", 1). The sentence 
In Amber or Swans we have an incipient Lucianic trend of correcting widespread false dóxa formed around him. He evades the literary categorization to which his familiar audience has subjected him and, while indirectly reorienting this reception too, he specifically guides his new audience by performing a subtle correction. Yet, within this orientation process, he cunningly works with the paradoxographer's deceiving pen. He defines himself through what he is not - an artist inventively lying, and his work through what it is not - mere lies. However, his stories here seem to contradict this assertive discourse of difference. By deceitfully ignoring the threshold between denotative and connotative, Lucian creates a sophisticated discourse in which parádoxa, obvious lies that others pass around as truth, are used for what they really are: exposed lies no longer masquerading as true stories. While they acquire a new value, almost inconceivable in a culture where value and truth are inseparable, the author himself appears as a parádoxon, one who condemns lying while, at the same time, enjoyably working and entertaining with naked lies. He still addresses, in a tacit conspiracy between storyteller and listener, the audience's concealed desire for pleasant lies. Instead of their searching far and wide for marvelous treasures and artistic pleasures, Lucian offers himself to the audience as an aesthetic parádoxon, unwrapped from the deceiving package of altering dóxa, yet wrapped in his own mystery as artist, resisting an easy perception while all the while cunningly claiming it.

As dóxa precedes him for the first time, a now established Lucian no longer looks for the approval of his audience, but for establishing a degree of difference in his reception. ${ }^{49} \mathrm{He}$ has overcome the complex of the fringe, of the barbarian not yet completely integrated into the

has a ring composition, starting with (at the expense of an inversion) and ending in

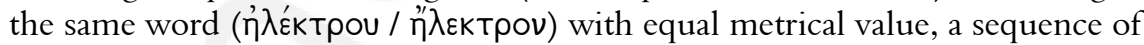

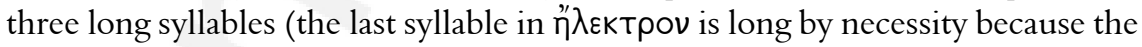
next period starts with a consonant). There are also other repetitions of the same

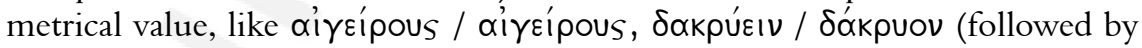

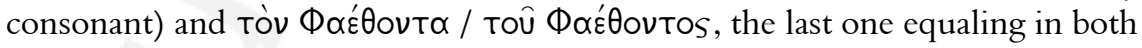
cases the end of a dactylic hexameter. The rhythm gains elevation through the careful use of other prosodic bits, like the sequence of four trochees in $\alpha \lambda \lambda \alpha \gamma \eta \hat{\eta} v \alpha$ ।

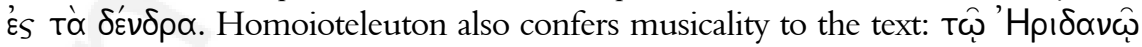
пот $\alpha \hat{\omega}$. The passage immediately following offers an even better example:

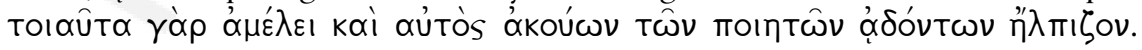
Obviously, even from the beginning, the text proves not to lack melodiousness.

${ }^{49}$ Cf. Nesselrath, op. cit., p. 125-126. 
core of Greekness. In Amber, Lucian is the Greek traveler in a remote, barbarian land. The locals laugh at him, just as the Athenians laughed at Anacharsis the barbarian, a sign that otherness is equally perceived as parádoxon by both sides, no matter the degree of cultural progress. In Amber, unlike The Scythian, the perspective of the wondrous, the exotic, is no longer that of a barbarian. It is Lucian's own perspective as culturally Greek, nourished by Greek myths. Lucian's eye for the parádoxon is here that of a Greek, reflecting the Greeks' perception of parádoxa, just as in The Dipsádes. Thus, Lucian seems to feel already embraced now into Greekness as its entitled citizen.

In Zeuxis or Antioch, part of Lucian's audience is in awe of his novelty:

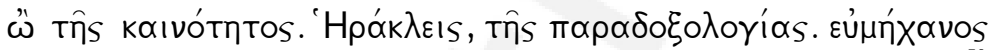

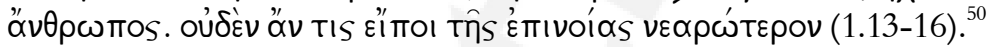

He aims to correct this perception and be admired not just for his literary exoticism, but also for his artistry, for creating an aesthetic marvel.

In the first illustrative anecdote, Lucian again displays his "painting with words", ${ }^{11}$ in the ékphrasis of a celebrated painting by Zeuxis. The famous painter, as an innovator in art, is the perfect example for Lucian's breaking with the literary generic tradition. Zeuxis' art is paradigmatic

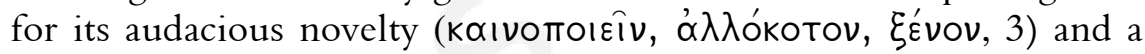
particular example of it is the innovative representation of a family of centaurs, a copy of which Lucian claims to have seen in Athens.

In his detailed description of the painting, Lucian pays a keen eye to the painter's skills ( $\tau \dot{\varepsilon} \chi \vee \eta)$, specifically to the precision of line, the suitable blending of colors and perfect brushwork, the masterful use of the effects of shadow, the perspective, proportion, and harmony of the parts. However, he particularly admires Zeuxis' variety and skillful

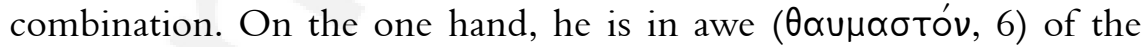
manifold genius of the painter's art (moıki $\lambda \omega s$ 5), illustrated by the diverse attitudes and emotions of the characters in the painting, from tenderness to wildness, especially in the image of the baby centaurs:

\footnotetext{
50 "Oh, what novelty! Heracles, what strange stories! What an inventive artist! No one could be more ingenious!"

${ }^{51}$ Luc. Dom. 21.14, Calumn. 2.1-2.
} 


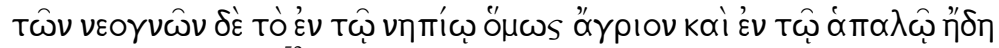
фоßєрóv (6.10-11). ${ }^{52}$

On the other hand, he praises the subtle technique of the chiaroscuro, of contrasts and transitions, perfectly exemplified by the beautiful image of the female centaur, in which the harmonious blending and joining of

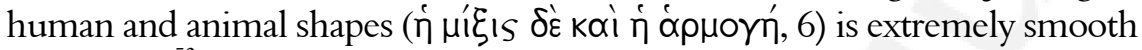
and gentle. ${ }^{53}$

Zeuxis expects to astonish his public with this display of his art

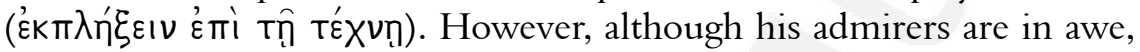
their response is due exclusively to the strangeness of his art object

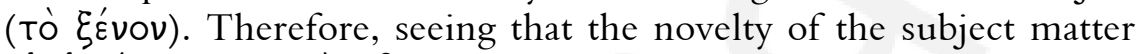
(í ú reception, his exquisite technique and detailed accuracy, Zeuxis decides to have the picture covered and taken back to his workshop. He protests with symbolic withdrawal, concealing art meant for display, thus de-creating the art object and abandoning the creative process.

In the second anecdote, Antiochus wins a spectacular victory against the Galatians by using elephants. ${ }^{54}$ The unexpected sight of the strange beasts (Tò $\pi \propto \rho \alpha ́ \delta \circ \xi \xi o$ ) brings the enemy into a state of shock and confusion. ${ }^{55}$ To the astonishment produced by the novel subject in the Zeuxis story, the centaurs, corresponds here astonishment from another

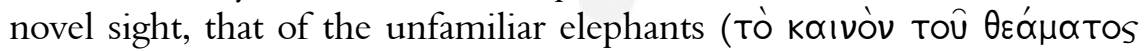
$\left.\dot{\varepsilon}^{\prime} \xi^{\prime} \bar{\varepsilon} \pi \eta \xi \xi, 11\right)$. The applicatio compares the perception of Lucian's display with an inadequate army saved only by elephants, or other strange monsters

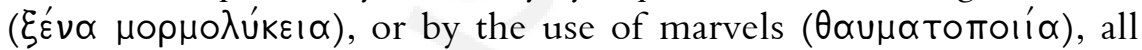

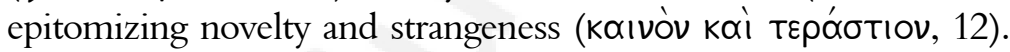

This prolaliá echoes A Literary Prometheus, a text most probably close in date, where Lucian talks in similar terms about his generic innovation, the mixis of dialogue and comedy. ${ }^{56}$ There too, Lucian uses

\footnotetext{
52 "As for the young ones, in their gentle infancy there was nevertheless something wild and in their tenderness something frightening".

${ }^{53}$ Cf. Rouveret, op. cit., p. 158-159.

${ }^{54}$ Cf. Xen. Hipp. 8.17-21 on surprise in military tactics.

${ }^{55}$ See Luc. Laps. 9 for a different version on the battle; cf. Just. Epit. 25; cf. Pol. 5.84-85 for the reaction of the African elephants to the Indian elephants in the battle of Raphia, 217 B. C., between Ptolemy IV and Antiochus III; Scullard, op. cit., p. 122; Sage, op. cit., p.208-210.

${ }^{56}$ Zeuxis is likely close in date not only to $A$ Literary Prometheus, which is probably earlier, but also to other texts that discuss more specifically Lucian's literary innovation (Luc. Bis acc., Pisc.); Hall, op. cit., p. 29.
} 
paradoxographical imagery and vocabulary to define his novel art object, which is associated with hybrid creatures, monstrosities of nature. Yet in A literary Prometheus, Lucian expresses his apprehension that his hybrid novelty might not be well received just as the blending of its conflicting parts might not be perceived as skillfully natural, but as an inconsistent mixture of genres, of familiar and unfamiliar, tradition and novelty. There, novelty as the result of literary hybridism still needs the author's advocacy and its salvation lies in the art of blending.

In Zeuxis, on the other hand, the author expresses strong confidence that he has already resolved the conflict of the elements combined in his literary melting pot, that he has already tamed his monster and attenuated its wild demeanor. In fact, his art of mixing, illustrated by Zeuxis' mastery of the palette, so competent that it creates the impression of the natural, is now accomplished. On it Lucian wishes to direct the focus of the audience's critical evaluation and enjoyment. Once innovation is acknowledged as the essential and distinguishing feature of his art, it is téchne - the ever-proper aesthetic criterion - that measures the value of the art object. At this level of judgment, novelty

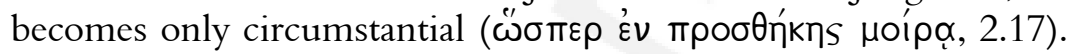

Lucian wants his audience to overcome the stage of perceiving his work as a generic parádoxon, a match for natural marvels, and to acknowledge it as an aesthetic parádoxon, a marvel of téchne. The artist himself shares the fortune of his art-object, which is the expression of self. Therefore, just as his art-object shifts its paradoxical nature, from novel and strange to an artistic marvel, the author too develops his cultural identity from non-Greek to Greek, from a parádoxon as a barbarian inventor to a parádoxon as an amazingly skillful artist working with the consecrated Greek canons. The reaction to novelty is purely emotional, while the response to an aesthetic marvel, equally strong emotionally, is filtered through paideí. While a passive paideía remains within the beaten path of fixed canons, which it sustains in an act of obedient mimesis that equals slavery, ${ }^{57}$ Lucian enacts here, for his audience, an active form of paideía as creative response to tradition, an artistic form of reflection on the familiar through the lens of otherness.

In Heracles, Lucian describes a painting of Heracles as Celtic Ogmios, which he claims to have seen in Gaul. ${ }^{58}$ The ékphrasis is gradually

\footnotetext{
${ }^{57}$ Cf. Mestre; Gómez, op. cit.

${ }^{58}$ Cf. Luc. Apol. 15 and Bis acc. 27 for his journey to Gaul. For an outline of the scholarly debate on the reality of such a painting and on the significance of the Celtic name see Nesselrath, op. cit., especially p. 133-134.
} 
built on parádoxa. Heracles is depicted as extremely old - a hýbris towards

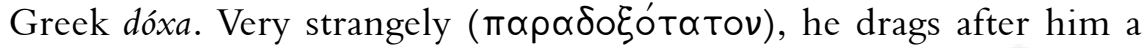
cheerful crowd, bound by their ears with delicate cords of amber and

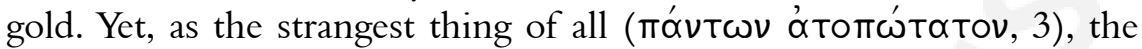
painter - supposedly in an aporetic gesture, since both of Heracles' hands are occupied with his traditional Greek attributes, the club and the bow - attached the chains to the pierced tongue of Heracles. This ingenious solution, the deus ex machina of his artistic craft, is the key point of the story. What now seems to the stranger an ingenious solution to a perplexity will be revealed as the painter's deliberate artistic choice of expressing his own culture. Lastly, as a final delicate touch to the climactic parádoxon, Heracles is turned towards his followers smiling, sealing with serene contentment the unconceivable, joyful association and conferring the parádoxon the status of pleasant norm (3).

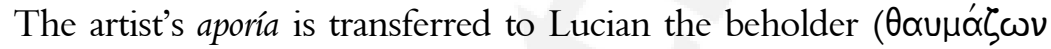

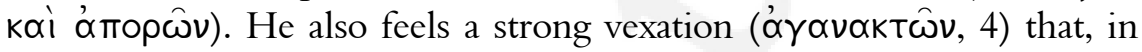
contrast with Heracles' peaceful smile, expresses his sense of hýbris. A vexed Lucian, coming from the Greek tradition, claims to feel his familiar world threatened. A local old man solves his perplexity by explaining that for the Celts Heracles is the god of speech, and thus reveals the painting as an allegorical representation of charming logos. ${ }^{59}$ The explanation of Heracles' old age lies in the fact that logos attains perfection at this stage in life, after a long process of maturation. Thus, the old Celt offers the rationalization of what was perceived as a parádoxon, undoing it and solving

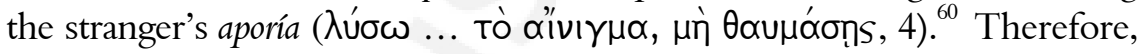
what seemed to the foreign beholder an expedient is now revealed as an artistic expression that requires a hermeneutical exercise. It becomes the

\footnotetext{
${ }^{59}$ Amato, op. cit., proposes the identification of the old Celt with Favorinus and suggests that the art object may be a literary text, Favorinus' De senect. (9-17 Barigazzi). ${ }^{60}$ On allegorical painting see Rouveret, op. cit., p. 346-354; cf. Tabula Cebetis, in which the painting represents a philosophical allegory and its explanation is

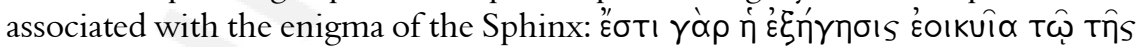

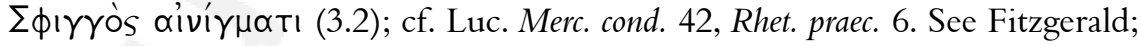
White, op. cit., on the problem of the association between Cebes of Thebes, the Socratic apprentice (Pl. Phaed.) and the Tabula. Cf. Max. Tyr. Or. 4.3-5 on the development of forms of expression from art, specifically poetry, to philosophy, from allegorical to straightforward discourse. Cf. Porph.Antr. 3-4 on fiction ( $\left.\pi \lambda^{\prime} \alpha \sigma \mu \alpha\right)$

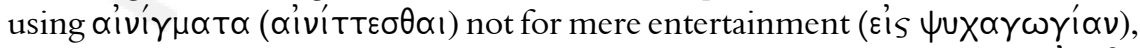
but as a form of argumentation for both philosophers and ordinary people (ou tois

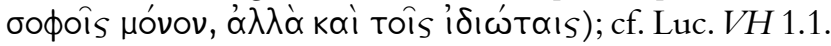


essence of the artistic creation and serves as a skillful allusion to the problems of interpretation of Lucian's own work. Thus, Lucian hints to his audience not to dismiss his rhetorical/ literary parádoxa as crafty expedients, but to exercise paideía in an attempt to understand them as valid and deliberate artistic means and to appreciate the subtleness behind them.

The old Celt is himself the result of a cultural mixis, being well educated in Greek culture, for which mastery of Greek language is both

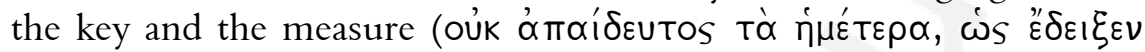

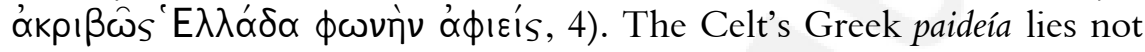
only in the perfect Greek he speaks, or in his ability to quote from Greek literature in order to support the arguments of the barbarian perspective on the matter of logos. It also finds its expression in his understanding of a Greek's perplexity when confronted with otherness. After Heracles, he is the second illustration for Lucian, himself of nonHellenic ethnicity and claiming to be now old too. They are both the result of a cultural mixis, have a more acute feeling of the otherness, and are able to translate it between different cultures.

The old Heracles represents the maturation of logos through paideía. Lucian confesses to a certain apprehension about returning to rhetorical epídeixis, submitting himself again $(\alpha u \hat{\theta} ı s, 7)$ to the judgment of a large educated audience. He anticipates that some of them, especially the young, might object to his daring (To $\lambda \mu \omega \hat{\nu}, 7)$, to his paradox of an old man acting in the spirit of the youth, in spite of his ripe age. Their objections, expressed - typically for pepaideuménoi - in literary quotations, contradict the argument built by the old Celt, and are then contradicted by Lucian himself in a classic sophistic exercise of díssoi lógoi. He supports his decision to start performing again, it is not clear after how long a hiatus, with the argument of the old persuasive Heracles. The flower of youth is spent in a long effort towards paideía and distilled in the blooming flower of logos. In a grand rhetorical manner, Lucian says farewell to youth and love: it is time now for the seasonably late and splendid bloom of eloquence to enthrall the audience in the manner of the Celtic Heracles.

Rhetorical persuasion in the realm of ideas, already undermined by the first sophists' skillful play with opposite arguments, has long lost its prominence through changes in the socio-political circumstances. Rhetorical display, epídeixis, targets now a different sensibility in the audience, the need for entertainment through paideía. Persuasion is often reduced to convincing the audience of the rhetor's skills. Lucian sees persuasion, now aesthetic in nature, as a type of rapture with words, similar to the forceful magic power of poetry and fiction/ fictitious 
discourse in general, such as Gorgias discusses in his Helen. ${ }^{61}$ Lucian puts a final touch on the prolalia through his comparison with Odysseus disguised as an old beggar, who astonishes the suitors when his might is unveiled from under the rags (Od. 18.66-74). Just like Odysseus, Lucian is mо入úтротоs, much travelled on the seas of rhetoric, having acquired multifaceted, versatile artistic skills, and master of a crafty, deceitful discourse. $^{62}$

After an alleged hiatus, Lucian returns to the rhetorical performance to re-establish himself by displaying and reaffirming his paideía before this audience of pepaideuménoi who, although silent, testify through their presence, to their long approval of his paradoxical stance and artistic worth. Willingly and cheerfully, they have long let themselves be enslaved to this barbarian Heracles, who smiles peacefully while dragging them by the ears through an enthralling adventure of amber and gold, beauty and paideía, the voyage of his toiling Greek logos.

In Dionysus, Lucian revisits the problem of reception through two Dionysiac mýthoi with pronounced paradoxographical features. ${ }^{63}$ The first mýthos narrates the Indian perception of the Dionysiac thiasos as a complex of parádoxa. While Dionysus and his troops approach their territory, the Indians send scouts to inspect the invaders. Lucian offers his audience a detailed description through their eyes, culturally unaccustomed to such a vision. ${ }^{64}$

Learning of an effeminate and hybrid army, the Indians do not find it a match for their military prowess. They avoid confrontation with such an unfit enemy, against which they consider, at most, to dispatch their women. However, when they learn that Dionysus' troops have set fire to their country, they hastily set out for battle, but encounter

${ }^{61}$ Gorg. Hel. 11-12; cf. Zeno fr. 278 (Diog. Laert. 7.24); cf. Plut. Rect. rat. aud. 37.f11$38 . b 3$ (on Theophr. fr. $91 \mathrm{~W}$ ).

${ }^{62}$ Cf. Jones, op. cit., p. 14. Cf. Luc. Zeux. 5.11; Hom. Od. 1.1, 10.330; Pl. Hp. mi. 369e 5-370a 2.

${ }^{63}$ Cf. Branham, op. cit., 1985 (and 1989), p. 43-46, p. 89-90; Nesselrath, op. cit., p. 135139; Georgiadou; Larmour, op. cit., p. 34-36; Ureña Bracero, op. cit., p. 49, p. 74-79, p. 81; Camerotto, op. cit., p. 120-129; Villani, op. cit.; Brandão, op. cit., p. 137-142; Santini, op. cit., p. 75. On attempts to couple it with a Lucianic text for which it served as prolaliá see cf. Thimme, op. cit.; Anderson, op. cit., 1976, p. 262-264; Georgiadou; Larmour, op. cit., p. 51-52.

${ }^{64}$ See Branham, op. cit., p. $44-45$ on the formalist concept of estrangement applied to this passage. 
terrible surprises, parádoxa. The frenzied, disarrayed thíasos becomes suddenly a well-organized army, while their noisy strategy still bears the marks of the boisterous Dionysiac revel. The Indians react to the

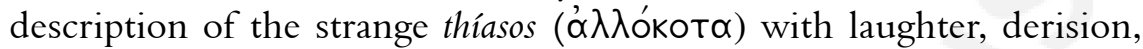

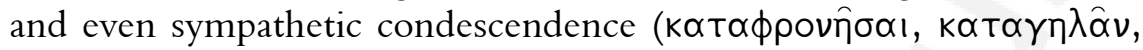

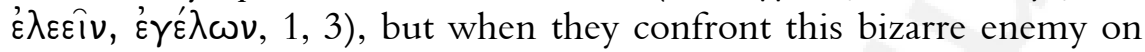
the battleground their immediate reactions are fright and disarrayed

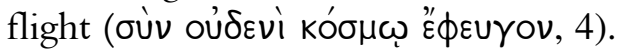

The Indians' reactions are paradigmatic of the different human responses to different types of parádoxa. Laughter mixed with condescendence is the typical response to human freaks, perceived always through the comparison not only with normality, but especially with one's own sense of self-normality. ${ }^{65}$ At the direct contact with the Donysiac parádoxa, the Indians become terrified and run away in an irrational fashion, as humans usually do when encountering animal monsters. ${ }^{66}$ These different reactions are also illustrative of human response to the degree of their contact with parádoxa, whether real or, at least partly, fictional, whether of autoptic perception or perceived through an intermediary (e.g. the writer of marvels or, here, the scouts). ${ }^{67}$ The distinction between reality and report, nature and logos, makes parádoxa entertaining, as in the case of paradoxography. In art, unlike in nature, parádoxa filtered through the creative genius of the artist become enjoyable and produce laughter. Yet this laughter is of a different sort: not derision, but the laughter of pleasure given by the experience of lógos and paideía.

Lucian deals here with two different levels of audience and paideía. Many (oi то $\lambda \lambda$ oí) are tempted to snub his novel performance (Toùs KaIvoùs $\left.\tau \hat{\omega} \nu \lambda^{\prime} \gamma \omega \nu\right)$, as the Indians snub Dionysus, having formed a wrong dóxa based on its comic appearance. Others, on the other hand, may come to enjoy exclusively the comic aspect of the performance. Bewildered by the author's subtly veiled serious stance (

\footnotetext{
${ }^{65}$ Pliny says that nature created strange creatures of the human race as a jest, amusement for herself and novel marvels for us (haec atque talia ex hominum genere ludibria sibi, nobis miracula ingeniosa fecit natura, HN 7.2.32).

${ }^{66}$ In Luc. Prom. es 4, the Egyptians manifest derision and repulsion towards a human

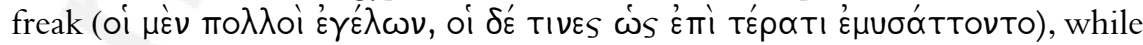

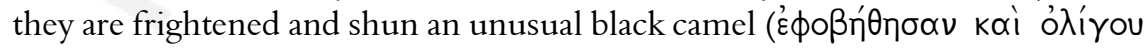

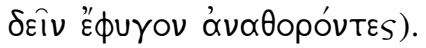

${ }^{67}$ Cf. Luc. Prom es; Zeux.
} 
they do not even dare to praise his display. Paradoxically, here Lucian calls the élite oi по $\lambda \lambda$ oi $_{\text {as }}$ the majority of his established audience, those many who, having forgotten the sacred communion they shared with him long

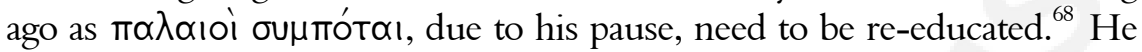
invites them to rekindle their communion and reminds them of the values of his paradoxical spoudogéloion. ${ }^{69}$ These are the usually serious audience,

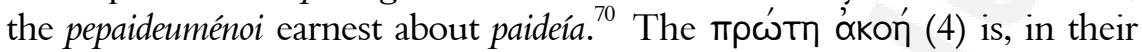
case, the first level of perception of his utterance that can induce a false dóxa. Those who come only for the comic appearance are instead biased either by a false report, or again by a mistaken interpretation. ${ }^{71}$ They, however, are not serious with respect to paideia and thus represent the non-élite. These need to be educated through the prolaliá. Their bewilderment and hesitation are the expression of their lack of paideía. All, however, will end up - Lucian confidently professes ( $\theta \alpha \rho \rho \omega \hat{v}$

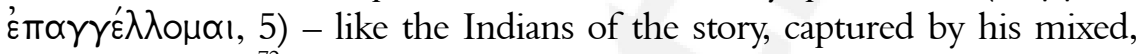
paradoxical lógos.

Both the élite and the non-élite have incomplete, although different, responses to Lucian's spoudogéloion, with some looking exclusively for the serious, others for the comic elements. A comprehensive reaction to spoudogéloion is attainable by an ideal élite, the pepaideuménoi, which Lucian does not always feel fortunate enough to have as audience. ${ }^{73}$ Yet he never stops, not even in his old age, encouraging pepaideuménoi to perfect themselves and to attain the level of subtlety and paideia that would allow them to grasp all the facets of his display.

\footnotetext{
the бuнто́таı as pepaideuménoi.

${ }^{69}$ Cf. Camerotto, op. cit., p. 128-129; Santini, op. cit., p. 76.

${ }^{70}$ Cf. Luc. VH 1.

${ }^{71}$ Cf. Luc. Electr. Camerotto, op. cit., p. 275.

${ }^{72}$ Cf. Luc. Herc.

${ }^{73}$ Cf. Santini, op. cit., p. 76; Camerotto, op. cit., p. 128-129.
}

${ }^{68}$ Santini, op. cit., p. 76-81 assumes that both groups represent the non-élite, usually

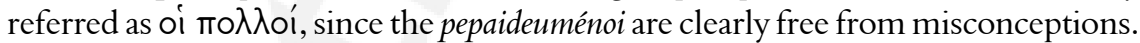
She argues that the pepaideuménoi are only the target of the second mýthos, deliberately left without an applicatio, because the élite would not need an explanation (on the lack of expressed applicatio for the second mýthos see also Villani, op. cit., p. 222). Santini misses the point that Lucian's invitation to be rejoined in the sacred rites of Dionysus by his old "revel companions" addresses the groups that she interprets as

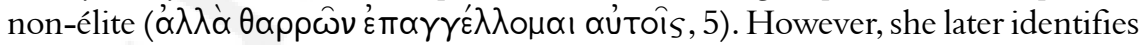


The second Dionysiac mýthos is focused on an Indian marvel. Old men drink once a year, during the festival of Dionysus, from a spring consecrated to Silenus and, becoming drunk and inspired, speak incessantly, yet charmingly. Yet the strangest thing of all

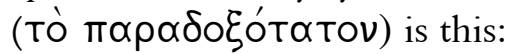

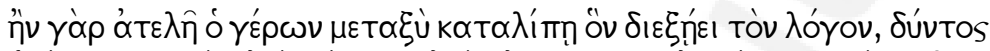

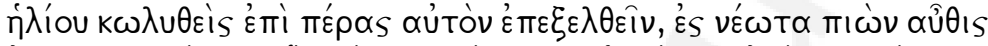

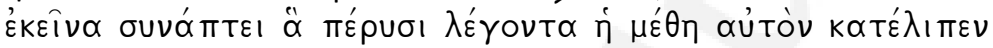
$(7.20-25) .^{74}$

This mýthos is left without an applicatio, in the spirit of the sacred and unutterable rites of Dionysus, yet understood by his audience as his fellow initiates and sympótai. Lucian associates himself with Silenus, thus with the Dionysiac mysteries, as well as with the logos of Socrates, whom Alcibiades likens, in a sympotic context, to the old companion of the god. ${ }^{75}$ The sequence of silence and eloquence is illustrative of Lucian's break followed by the comeback to rhetorical performance. ${ }^{76}$ It is also a reference to his consistency, in spite of the hiatus, in practicing in old age the same type of rhetoric he professed when younger. It may also be an ironical anticipation of a long performance to follow. This prolalia, whether or not Lucian's last, bears testimony to his continuous struggle to validate his generic mixis, including the serio-comic, as well as the mixis of enthrallment and thoughtful logos. He invites his sympótai to drink from his cratér, to have their fill of his literary mixing bowl.

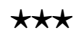

So what has this Dionysus to do with Dionysus? What has this Lucian - with his ever-changing faces, from the young inexperienced

\footnotetext{
${ }^{74}$ "If an old man stops in the middle of his discourse, interrupted by the sunset, next year, drinking again, he resumes it, where drunkenness/ inspiration left him the year before". On water, wine and/ or madness see Luc. VH 1.5-7; Antig. 145, 149, 164; Par.Flor. 1, 12, 13, 14, 18, 20, 24; Par.Pal. 5; Par. Vat. 12, 22.

${ }^{75}$ Pl. Symp. 215a-b; Ureña Bracero, op. cit., p. 76-77; Camerotto, op. cit., p. 129 n. 222; Santini, op. cit., p. 84 (Lucian's “modelli di eloquenza sono il 'divino' Socrate e il trascinante Odisseo"); for a detailed parallel reading of Pl. Phaedr. and Luc. Bacch., including the interminable speech of Socrates vs. that of Silenus see Santini, op. cit., p. 85-86.

${ }^{76}$ Cf. Villani, op. cit., p. 221.
} 
Harmonides to the old, seducing Heracles - to do with Lucian? ${ }^{77}$ The prolaliai offer a glimpse at different stages of his rhetorical career, from the hesitant young barbarian looking for the proxenía and philia of the Greek élite, to the accomplished Greek looking for approval for his harmoniously blended hybrids, from the bewildered stranger to the bewilderment of the Greeks. If parádoxa are equally a favorite delight and an instrument of seduction, Lucian uniquely makes them his own. ${ }^{78}$

In these little pieces that serve as "hors-d'œuvre au repas verbal", Lucian uses parádoxa for their value per se, to shock and please, as useful tricks from the sophist's rich bag, but also as paradigms for his work and its reception. He constantly addresses the pepaideuménoi from whom he expects a reaction different from that of the non-élite, whom he usually sets in parallel with barbarians (Egyptians, Galatians, and Indians). His intended effect upon the audience is a more complex form of ékplexis coming both from novelty and from téchne. This different type of reception is illustrated by another sort of barbarian, presented not as an ethnic group, but individualized and named, bewildered by Greek paideía (Anacharsis, Toxaris). He elevates the pleasure produced by parádoxa from the level of a (pseudo-)cognitive emotion to an aesthetic one. Ekphrastic discourse, a favorite rhetorical exercise in the Lucianic corpus, praises other art objects for their beauty, their marvelous eídos. Lucian, in turn, elevates discourse itself to a parádoxon as aesthetic marvel, both as paradoxical genre eídos and téchne. ${ }^{80}$

\section{Bibliography}

AMATO, E. Luciano e l'anonimo filosofo Celta di "Hercules" 4: proposta di identificazione. SO, Oslo, vol. 79, p. 128-149, 2004.

ANDERSON, G. Some alleged relationships in Lucian's "Opuscula". AJP, Baltimore, vol. 97, n. 3, p. 262-275, 1976.

ANDERSON, G. Patterns in Lucian's “prolaliaí”. Philologus, Göttingen, vol. 121, p.313-315, 1977.

\footnotetext{
${ }^{77}$ Luc. Bacch. 5.1-2.

${ }^{78}$ Lucian's parádoxa are more prominent and more sophisticated than the famous triple paradox of Favorinus; Philostr. VS 489.11-16; Gleason, op. cit.

${ }^{79}$ Reardon, op. cit., p. 165.

${ }^{80}$ Cf. Giannini, op. cit., p. 249-250.
} 
ANDERSON, G. The Second Sophistic: a cultural phenomenon in the Roman Empire. London: Routledge, 1993.

BASLEZ, M.-F. L'étranger dans la Grèce antique. Paris: Les Belles Lettres, 1984.

BEAGON, M. The Elder Pliny on the human animal: "Natural History”, Book 7. Oxford: Clarendon Press, 2005.

BELFIORE, E. Ovid's encomium of Helen. CJ , Provo, UT, vol. 76, n. 2, p. 136148, 1980-1981

BÉLIS, A. Un “Ajax" et deux Timothée: (P. Berol. n 6870). REG, Paris, vol. 111, n. 1, p. 74-100, 1998.

BÉLIS, A. Timothée, l'aulète thébain. RBPh, Bruxelles, vol. 80, n. 1, p. 107-123, 2002.

BOMPAIRE, J. Lucien écrivain, imitation et création. Paris: E. de. Boccard, 1958.

BRANDÃO, J. L. A poética do Hipocentauro: literatura, sociedade e discurso ficcional em Luciano de Samósata. Belo Horizonte: UFMG, 2001.

BRANHAM, R. B. Introducing a sophist: Lucian's prologues. TAPA, Cleveland, OH, vol. 115, p. 237-243, 1985 (republished in BRANHAM. Unruly eloquence. Cambridge, MA: Harvard University Press, 1989).

CAMEROTTO, A. Le metamorfosi della parola: studi sulla parodia in Luciano di Samosata. Pisa: Istituti editoriali e poligrafici internazionali, 1998.

EVANS, J. A. S. Father of History or father of lies: the reputation of Herodotus. CJ, Provo, UT, vol. 64, n. 1, p.11-17, 1968.

FITZGERALD, J. T.; WHITE, L. M. The tabula of Cebes. Chico, CA: Scholars Press, 1983.

FRASER, P. M. Ptolemaic Alexandria. Oxford: Oxford University Press, 1972.

GALLAVOTTI, C. Luciano nella sua evoluzione artistica e spirituale. Lanciano: Giuseppe Carabba, 1932.

GEORGIADOU, A.; LARMOUR, D. H. J. The "prolaliae" to Lucian's "Verae Historiae”. Eranos, Oxford, GA, vol. 93, p. 100-112, 1995.

GIANNINI, A. Studi sulla paradossografia greca, I. Da Omero a Callimaco: motive e forme del meraviglioso. RIL, Milano, vol. 97, p. 247-266, 1963.

GLEASON, M. W. Making men: Sophists and self-presentation in Ancient Rome. Princeton: Princeton University Press, 1995.

GORRINI, M. E. Toxaris, ó Ǵvvos iarpós. Athenaeum, Pavia, vol. 91, n. 2, p. 435-443, 2003.

HALL, J. A. Lucian's satire. New York: Arno, 1981.

HARTOG, F. Le miroir d'Hérodote: essai sur la représentation de l'autre. Paris: Gallimard, 1980.

HORDERN, J. H. The fragments of Timotheus of Miletus. Oxford: Oxford University Press, 2002. 
JOHNSON, W. A. Oral performance and the composition of Herodotus' "Histories". GRBS, Durham, NC, vol. 35, n. 3, p. 229-254, 1994.

JONES, C. P. Culture and society in Lucian. Cambridge, MA: Harvard University Press, 1986.

KINDSTRAND, J. F. Anacharsis: the legend and the "Apophthegmata". Uppsala: Uppsala Universitet, 1981.

MESTRE, F.; GÓMEZ, P. Retórica, comedia, diálogo: la fusión de géneros en la literatura griega del s. II d.C. Myrtia, Murcia, vol. 16, p. 111-122, 2001.

MRAS, K. Die $\pi \rho \circ \lambda \alpha \lambda ı \alpha$ bei den griechischen Schriftstellern. WS, Wien, vol. 64 , p. 71-81, 1949.

NESSELRATH, H. G. Lucian's introductions. In: RUSSELL, D. A. (org.). Antonine literature. Oxford: Clarendon Press, 1990, p. 111-140.

PERNOT, L. La rhétorique de l'éloge dans le monde gréco-romain. Paris: Institut d'études augustiniennes, 1993.

REARDON, B. P. Courants littéraires grecs des IIe et IIIe siècles aprèsJ.-C. Paris: Les Belles Lettres, 1971.

ROBINSON, C. Lucian and his influence in Europe. London: Duckworth, 1979.

ROTHSTEIN, M. Quaestiones Lucianeae. Berlin: Mayer und Müller, 1888.

ROUVERET, A. Histoire et imaginaire de la peinture ancienne: Ve siècle av.J.C.-Ier siècle ap. J.C. Rome: École Française de Rome, 1989.

RUSSELL, D. A. Greek declamation. Cambridge: Cambridge University Press, 1983. SAGE, M. M. Warfare in ancient Greece. London/ New York: Routledge, 1996.

SANTINI, L. Autoritratto dell'artista: Luciano nella prolaliá "Dioniso". AUFL, Ferrara, n. s. 2, p. 73-97, 2001.

SCHEPENS, G.; DELCROIX, K. Ancient paradoxography: origin, evolution, production and reception. In: PECERE, O.; STRAMAGLIA, A. (org.). La letteratura di consumo nel mondo greco-latino. Cassino: Università degli studi di Cassino, 1996, p. 375-460.

SCULLARD, H. H. The elephant in the Greek and Roman world. Ithaca, NY: Cornell University Press, 1974.

SEGAL, C. P. Gorgias and the psychology of the "Logos". HSPh, Cambridge, MA, vol. 66, p. 99-155, 1962.

STOCK, A. De prolaliarum usu rhetorico. Königsberg Diss. Königsberg: Hartung/ Regimonti, 1911.

THIMME, A. Zwei Festvorlesungen des Lukianos. Jahrbücher für klassische Philologie, Leipzig, vol. 37, p. 562-566, 1888.

UNGEFEHR-KORTUS, C. Anacharsis, der Typus des edlen, weisen Barbaren: ein Beitrag zum Verständnis griechischer Fremdheitserfahrung. Frankfurt am Main/New York: P. Lang, 1996. 
UREÑA BRACERO, J. El diálogo de Luciano: ejecución, naturaleza, y procedimientos de humor. Amsterdam: A.M. Hakkert, 1995.

VILLANI, B. L'ironia nelle “prolaliáe” di Luciano. Quaderni del Dipartimento difilologia linguistica e tradizione classica, Bologna, p. 217-233, 2000.

VISA-ONDARÇUHU, V. Parler et penser grec: les scythes Anacharsis et Toxaris et l'expérience rhétorique de Lucien. REA, Paris, vol. 110, n. 1, p. 175-194, 2008.

WEST, M. L. Ancient Greek music. Oxford: Oxford University Press, 1992.

WHITMARSH, T. Greek literature and the Roman Empire: the politics of imitation. Oxford: Oxford University Press, 2001.

WHITMARSH, T. The Second Sophistic. Oxford: Oxford University Press, 2005. 